\title{
Continuous Professional Development of English Language Teachers: Perception and Practices
}

\author{
AbdulRahman Al Asmari \\ Associate Professor, Faculty of Arts, Taif University, At-Taif, Saudi Arabia \\ E-mail: abdulasmari@gmail.com
}

Doi:10.7575/aiac.alls.v.7n.3p.117

URL: http://dx.doi.org/10.7575/aiac.alls.v.7n.3p.117
Received: 17/01/2016

Accepted: 10/03/2016

\begin{abstract}
Professional development is considered as an essential element in enhancing the teaching and learning process to ensure student learning. Professional development can also be deemed as a cornerstone of teacher professionalism and quality. The governments and educational institutions invest significantly in Continuous Professional Development (CPD) to improve teacher quality and to meet the changing needs of the students. To uncover the perceptions and practices of professional development in Saudi Arabia, a survey was conducted at Taif University English Language Centre. The sample consisted of 121 English language teachers from various countries and having varied educational and academic experiences. The survey comprised items relevant to learning approaches, concept of professional development, perceptions and feedback on CPD. The respondents supported lifelong learning and experiential learning leading towards learner centered approach. They perceived the CPD as a challenge to their existing knowledge and classroom practice. However, they expressed their concerns regarding indigenization of activities in CPDs, institutional support in conducting classroom activities, and follow up activities.
\end{abstract}

Keywords: Professional development, Teacher perception, ELT in Saudi Arabia

\section{Introduction}

A person having opportunities to learn and grow can better provide such opportunities to the students as well. Wood (cited by Hargreaves \& Fullan, 1992) contends that "opportunities to learn also require opportunities to teach" (p. 1). The twentieth century witnessed the emergence of a number of educational theories and methods to improve the quality of teaching and learning process. In order to be abreast with the change, Continuous Professional Development (CPD) is growingly becoming an essential element for teachers' career advancement. Hargreaves and Fullan (1992) argue that CPD is necessary to raise the quality of educational standards because teachers need to go ahead continually by equipping themselves with the knowledge and skills to enhance their teaching skills and students' learning opportunities. Besides coping with the change, a teacher needs to be a model for his students as a life-long learner, so he must exhibit their dedication and enthusiasm towards continuous learning as their primary duty is to make their students life-long learners (Day, 1999).

English language teaching (ELT) is a significant field due to the importance of English around the world, and an English language teacher has to keep updated with the changes and innovation in their field. Professional development is pivotal as a foundational element in teachers' development (Luke \& McArdle, 2009) and to stay abreast with the rapidly evolving field of ELT (Curtis cited in Bailey, Curtis, \& Nunan, 2001) for being an effective foreign language teacher. Golding and Gray (2006) and Jasper (2006) enlist various reasons of a teacher's participation in a CPD program which include an interest in lifelong learning, a sense of moral obligation, a felt need to enhance teaching skills, an institutional requirement, and/or for career advancement. In the EFL/ESL context, different aspects of paradigm shift in second language teacher education (Jacobs \& Farrell, 2001) have rendered CPD urgent for teachers, who are largely influenced by traditional models of teaching (Lau, 2006). An English language teacher needs to manage classroom activities effectively and to have a good deal of knowledge and comprehension of many factors and variables that control and govern the process of learning and teaching in the classroom situation. The need to develop professionally as English language teachers necessitates an active engagement in the learning process in which numerous development activities for English language teachers have become handy for the purpose of self-development (Karaaslan, 2003, p.4). Previous research has demonstrated the value of CPD that actively involves practicing teachers in the process of learning (Kerka, 2003; Muijs \& Harris, 2003; Hargreaves \& Fullan, 1998; Darling-Hammond \& McLaughlin, 1995; Sparks \& Loucks-Horsley, 1990).

Several previous studies (e.g. Shang, 2010; Lau, 2006; Fullan \& Hargreaves, 2002; Jacobs \& Farrell, 2001; Hayes, 2000) have also demonstrated that CPD can impact positively on educational processes and outcomes. There are various means of professional development including self-development, self-reflection, peer teaching/ observation/ supervision, in-service training, short-term courses, seminars, conferences, mentoring, in-house training sessions, etc. There has 
been a continuous debate regarding CPD which tackled such issues as who and what is being developed, by whom and, most importantly, in whose interests (Nofke cited in David, Olwen, Janis, Mary \& Anne, 2003).

English is mostly the medium of instruction at the higher education institutions in Saudi Arabia. Professionalism in teaching English as a Foreign Language (EFL) in Saudi Arabia has been affected by wide-ranging reforms in education such as curriculum, instruction, and assessments with the intention of achieving better education for Saudi learners to match the challenging educational demands of life and work in the 21st century (Badia, 2015). As such, the rapid changes in the educational scenario compel the teachers to work hard in order to respond to such changes effectively through CPDs. This means that teachers are required to be qualified to have high-level of knowledge in education which in turn advances their own professional knowledge and could also lead to the development of their teaching as a profession. These tendencies can be affected by many factors such as personal, educational and social factors which shape the status of being a professional teacher (Badia, 2015).

\section{Literature Review}

The $21^{\text {st }}$ century started with the concept of globalization and learning other languages is vital to be a part of this process. It not only increased the number of learners of other languages, but it also initiated research in foreign or second language teaching and learning. Effective language study is focused on communication, facilitating the development of knowledge and skills in language and culture, integrating language acquisition with content from other subject areas, and preparing students to be lifelong learners and users of the skills, information, and insights they gain. The study of English amongst the other subject matters has become vital to cope with the world of technology and business around the world. Therefore, the teachers of English need to be updated with the knowledge and skills necessary to their professional growth and be a lifelong learner.

With the introduction of new methods and techniques, the role of a language teacher has changed (Turhan \& Arikan, 2009; Bailey, 1992; Willis \& Willis, 1996) and this change can refer to many things including knowledge, beliefs, attitudes, understanding, self-awareness and teaching practices (Bailey, 1992; Jackson, 1992). Classroom is a site that provides opportunities for experimentation, exploration, and change for both teachers and learners. Thus, to make it clear, innovation and change is a necessary part of teacher development (Allwrite cited in Yurtsever, 2012).

Much literature is available which engages teachers' professional growth, either pre-service or in-service. Here we need to understand the difference between teacher education and professional development. Díaz-Maggioli (2004) argues that in teacher education, teachers are recipients of knowledge presented by the experts in the field so the traditional development is not context- or teacher-sensitive. On the other hand, professional development means helping teachers grow in their profession which is a constructivist perspective to learning. Richards and Farrell (2005) use the terms training and development in the same context. They think training means preparing teachers for the teaching task, teaching situations, material adaptation, and grouping learners. However, development involves teachers' knowledge of themselves and of their teaching situations and it"often involves examining different dimensions of a teacher's practice as a basis for reflective review" (Richards \& Farrell, 2005, p. 4). Another important aspect in professional growth is continuity as it is a lifelong process. Little (1993) stated that professional development offers meaningful, intellectual, social, and emotional engagement with ideas, materials, and colleagues both in and out of teaching. According to Freeman (1989), professional development is a strategy of influence and indirect intervention that works on complex, integrated aspects of teaching. The purpose of development is for the teacher to generate change through increasing or shifting awareness (Giraldo, 2014). Richards and Farrell (2005) further clarifies the concept of professional development that it serves as a longer-term goal and growth of teachers' understanding of teaching and of themselves as teachers. These goals may include: Understanding the process of language development, understanding change in teachers' roles according to the kind of learners, understanding the kinds of decision-making during lessons, reviewing one's own theories and principles of language teaching, developing an understanding of different styles of teaching, and determining learners' perceptions of classroom activities (p 4).

\subsection{Relevant Studies}

Atikler (1997) conducted a research on the relationship between the action research and self-development of English language teachers in accumulating knowledge of teaching situation, developing teaching skills and enhancing awareness of personal and professional aspects of teaching. His findings indicated that the participants experienced selfdevelopment in terms of knowledge, skills and awareness of teaching practice.

Renyi (1998) conducted a survey of CPD opportunities, interviewed teachers, conducted focus group discussions with the teachers who took charge of their professional development opportunities. The findings revealed that they viewed $\mathrm{CPD}$ as a continuous need throughout their careers in keeping up with changing knowledge, changing students, and a changing society.

Bailey, Curtis, and Nunan (1998) utilized journals, videotaping, and teaching portfolios with teacher educators. They concluded that CPD is a matter of self development just as teachers cannot do the learning for the learners, teacher educators cannot do the learning for pre- or in-service teachers. They argued that use of any of these activities could lead to effective professional development.

Investigating the effectiveness of action research, Özdemir (2001) analyzed the changes and improvements it brings to teaching. The data were collected through a research journal, an observation checklist, and action research reports 
written by the teachers. The researcher observed a positive change in their teaching style, a change in their views, perspectives, beliefs and ideas regarding language teaching, an awareness of other views and ideas by accessing the existing literature in the field. They concluded that action research contributed to teachers' professional self development and they were able to overcome the current problems in their classes through the application of some techniques and strategies.

ORC International (2001) carried out a research on 38 teachers from primary and secondary schools engaging them in discussion groups. The research showed that the teachers wanted to explore new ideas through discussions with teachers in their own and other schools. Also the participants valued sharing good practice very high and they were able to organize limited resources more effectively. The main problems expressed regarding CPD were the availability of resources and administrative support.

Lam, Yim, and Lam (2002) found that a considerable percentage of teachers did not welcome their peers to their classrooms and peer collaboration for staff development is rarely practiced in Hong Kong. If classroom teaching is observed or discussed, it was mostly for the sake of staff appraisal. The educators faced two challenges: Detaching the discussion and observation of classroom teaching from staff appraisal and securing a niche for it in the practice of staff development.

Al-Manwari (2003) concluded that the most common PD activity done by the teachers in the Omani schools was peer observation. Also, Al-Hashami (2003) explored the professional development needs of Omani teachers and stated that the current training hours for teachers are not adequate. He suggested that an additional allocation of time for PD be provided by the institutions.

In Álvarez and Sánchez's (2005) study, the researchers found that the teachers were aware of their teaching practices and of the need to update themselves continuously. In CPD, the participants had a chance to share pedagogical ideas and improve their teaching skills. In activities, the teachers played the role of learners, a technique that was meaningful for them as they became aware of teaching issues that affect learners.

Ariza and Ramos (2010) conducted an action research study and found that the teacher study group (TSG) allowed the participants to make connections between theory and practice, and provided them a space to receive colleague support for problematic areas in their own teaching contexts. Also the researchers found that the TSG helped the participants to become more reflective about their teaching practice.

Badia (2015) conducted a research at the English Language Institute (ELI) at King Abdulaziz University (KAU), Saudi Arabia. The researcher used teacher evaluation and appraisal process as a tool for professional development. Data was collected from 30 teachers from seven different nationalities with diverse qualifications and teaching experiences. It was found that there is a variation of opinion held by the participants on the current evaluation and appraisal process at ELI. The findings of this study revealed that the teachers supported the common belief that the teacher evaluation and appraisal processes could enhance the level of professional development and lead to the teaching improvement if conducted in a constructive approach. On the other hand, they expressed dissatisfaction with the current schemes of the teacher evaluation system at ELI and opined that the appraisal system practiced at their institution was not objective enough to measure their performance properly, calling for the trained and objective observers to conduct a fair evaluation.

The overview of research conducted in the field provides an impetus for the present study, which seeks to explore how EFL teachers in Saudi Arabia can be made to play a more active role by participating in a CPD, and how such a mode of CPD can foster teacher learning in a professional learning community.

\subsection{Research Questions}

1. What is the attitude of English language teachers toward their own professional development?

2. How do the English language teachers perceive a CPD program?

3. What's the feedback of the English language teachers on a CPD program?

\section{Method}

In this survey research, a questionnaire was designed for the participating teachers (121) in a CPD organized at the English Language Centre, Taif University (TUELC), Saudi Arabia. The questions were designed using Lickert scale (from 5-maximum to 1-minimum) regarding professional development. The questionnaire consisted of three parts: Selfdevelopment, perceptions on a CPD, and feedback on a CPD. The questionnaire was administered to 121 teachers (male and female) at the English Language Centre. The teachers have varied backgrounds in terms of nationalities, qualifications and experiences, but they teach English to the first year university student. The data reflected perceptions and feedback on an ongoing CPD and future expectations. The responses were analyzed using the SPSS.

\section{Result and Discussion}

Data collected through the survey were tabulated on Lickert scale (5-1). Accordingly, data were analyzed and presented thematically as follows: Self-development, perception regarding CPD, and feedback on CPD. 
Part A: EFL teaches attitudes toward self-development

Table 1. Attitudes toward self-development

\begin{tabular}{rrr}
\hline \multicolumn{2}{c}{ Statements } & Response (Scale 5-1) \\
\hline 1 & I often engage myself in difference self-development activities: \\
a. Set my own learning goals to improve myself professionally & 4.42 \\
b. Reflect on my practice as a teacher & 4.34 \\
c. Seek out professional literature to address my professional learning needs & 4.02 \\
d. Approach colleagues to provide me with professional help or guidance & 3.90 \\
e. Provide assistance to a colleague to help them solve a problem and/or & 4.16 \\
& improve their teaching practice & 4.22 \\
f. Share new and innovative ideas with my colleagues
\end{tabular}

The first section focused on different self-development activities adopted by the teachers to improve their teaching as shown in Table 1. Data analysis shows that respondents set their own learning goals to improve professionally (4.43) and reflect on their own teaching practices (4.34). Such teachers have their own purposes for development, and in this process, teacher learning may be enhanced by engaging teachers in professional sharing and critical reflection and by helping them to adapt knowledge to specific contexts. Also, respondents seem to favor sharing new and innovative ideas with their colleagues (4.22) and providing assistance to a colleague helping them to solve a problem or improve their teaching practice (4.16). This attitude reflects a constructivist approach in which teachers are more participative and the development is conducted in a bottom up process in which knowledge is at least partly constructed through engagement with experience, reflection and collaboration. At the same time, participants (4.02) opined that they seek out professional literature to address their professional learning needs. In this regard, self-development bears a great significance for professionals to have an active role in their own development processes. By engaging in professional sharing with their peers, they also build a collaborative culture and foster learning in professional learning communities.

Part B: EFL teachers' perception regarding CPD

Table 2. Perceptions regarding CPD

\begin{tabular}{|c|c|c|}
\hline & Statements & Response (Scale 5-1) \\
\hline \multirow[t]{13}{*}{2} & How do I perceive the CDP: & \\
\hline & a. Having fun with other teachers & 3.32 \\
\hline & b. Networking with other teachers & 3.43 \\
\hline & c. Listening to an expert & 3.80 \\
\hline & d. Gaining new ideas to try out in the classroom & 3.98 \\
\hline & e. Being challenged to think creatively and critically as a learner and teacher & 3.66 \\
\hline & f. Being energized and affirmed to set goals in pursuit of teaching excellence & 3.58 \\
\hline & g. Quick fixes to problems or concerns & 3.34 \\
\hline & h. Instructions from 'experts' & 3.38 \\
\hline & i. Reflecting on my own practice & 3.74 \\
\hline & j. Learning with and from my colleagues & 4.16 \\
\hline & k. Provide opportunities to apply my learning in my classroom & 3.68 \\
\hline & 1. Certificates as evidence of my learning & 3.60 \\
\hline
\end{tabular}

This section discusses the perceptions of the participating teachers in a CPD as demonstrated in Table 2. Data analysis shows that respondents perceived learning with and from their colleagues (4.16), gaining new ideas to try out in the class (3.98), and listening to an expert (3.80). Their perception reflects collaborative learning and self-directed learning which they seem to believe in, as similarly displayed in section A. The data may reflect their intension and purposes as self-learner, but at the same time they expressed their apprehension regarding the CPD as well. They shared that CPD may provide opportunities to apply their learning in the course (3.68), being challenged to think creatively and critically as a learner as well as a teacher (3.66), and being energized and affirmed to set goals in pursuit of teaching excellence (3.58). This highlights issues relating to the course management, its duration and number of participants. The duration of the CPD is one week and the number of participants reaches 80 (for each gender). It can be observed that the available space may not be enough to cater the needs of such a large group at the same time. This also may hinder the inaction between the trainer and the participants, and among the participants. Further, not all the participating teachers get a chance to share their ideas or reflect upon their teaching during a session. However, they expressed their concerns 
regarding networking with colleagues (3.43), instructions from experts (3.38), and quick fixes to their problems/issues (3.34). Such problems may emerge from the course management which was bound to exercise large group distribution, short duration of the workshops, and all that might have resulted in less interaction.

\section{Part C: Feedback on CPD}

Table 3. Feedback on CPD

\begin{tabular}{|c|c|c|}
\hline & Statements & Response (Scale 5-1) \\
\hline 3 & The CDP is very important in developing my teaching skills. & 3.78 \\
\hline 4 & The CPD has covered a wide range of ELT themes. & 3.68 \\
\hline 5 & Activities carried out during the CPD are effective. & 3.30 \\
\hline 6 & The CPD includes a variety of activities designed for adult learners. & 3.28 \\
\hline 7 & CPD provided a change to learn with and from my colleagues. & 3.80 \\
\hline 8 & The CPD includes continuous support and follow-up activities. & 3.12 \\
\hline 9 & The CPD expects changes in teachers' classroom practices. & 3.54 \\
\hline 10 & $\begin{array}{l}\text { The CPD provides challenging changes in knowledge, skills, attitudes, and beliefs } \\
\text { of participants. }\end{array}$ & 3.50 \\
\hline 11 & The learning climate of PD activities is collaborative, informal, and respectful. & 3.62 \\
\hline 12 & The program leader is knowledgeable and has credibility with the participants. & 3.86 \\
\hline 13 & $\begin{array}{l}\text { All CPD activities include theory, demonstration, practice with feedback, and } \\
\text { coaching. }\end{array}$ & 3.44 \\
\hline 14 & The CPD has a research base similar to the ELC situation, community and context. & 3.28 \\
\hline 15 & $\begin{array}{l}\text { A norm of experimentation exists which permits educators to try on new } \\
\text { instructional practices. }\end{array}$ & 3.44 \\
\hline 16 & Every teacher continues to refine their skills and knowledge. & 3.58 \\
\hline 17 & $\begin{array}{l}\text { Leadership advocates, encourages, and supports professional development through } \\
\text { incentives and resources. }\end{array}$ & 3.50 \\
\hline 18 & CPD is aligned with ELC strategic plan including mission, goal and objectives. & 3.46 \\
\hline 19 & The faculty has ongoing discussion groups on professional development issues. & 3.36 \\
\hline 20 & Teachers have regular and equal access to professional development programs. & 3.68 \\
\hline 21 & $\begin{array}{l}\text { The CPD approach has both long-term and short term goals tied to ELC } \\
\text { improvement plan. }\end{array}$ & 3.78 \\
\hline 22 & $\begin{array}{l}\text { I model continuous upgrading of my own professional development and leadership } \\
\text { skills. }\end{array}$ & 4.00 \\
\hline
\end{tabular}

As displayed in Table 3, last section of the questionnaire focused on the feedback on the CPD. Majority of the teachers opined that they model continuous upgrading of their professional and leadership skills (4.00). This reflects their motivational level and a quest for self-development. They also appreciated the role of the CPD coordinator (3.86). They conveyed that the CPD provided them with a chance to learn with and from their colleagues (3.80), realized CPD's importance in developing their teaching skills (3.78), acknowledged regularity and accessibility to CPDs (3.68), covered a wide range of ELT themes (3.68), and learning environment was collaborative, informal, and respectful (3.62). Most importantly, the CPD had both long and short term goals tied to the TUELC improvement plan (3.78).

To some extent, respondents were of the view that all the teachers continued to refine their skills and knowledge (3.58), CPD expects changes in their classroom practice (3.54), and the CPD provided them challenging change in their knowledge, skills, attitudes, and beliefs (3.50). The reason may be due to the varied educational backgrounds and teaching experiences of teachers from different countries. Besides, their motivational level may be different. Participants also expressed that the leadership advocates, encourages, and supports professional development through incentives and resources (3.50). Though the institutional support was there, but there were concerns regarding incentives and resources after bringing in a change into their classroom teaching and student learning.

From another perspective, respondents expressed their concern on various aspects of the CPD which may be classified into three categories: Institutional policies and support, indigenization of activities carried out during the CPD, and follow-up activities. Regarding the institutional policies, the respondents mentioned that CPD is aligned with the TUELC strategic plan (3.46), and CPD has a research base similar to the TUELC situation, community, and context (3.28). This reflects that either the participants are not acquainted with the institutional policies or do not take an active part in the institutional activities for students and community. Other reasons could be the university scattered campuses 
around city as well as the teachers being over-burdened with academic activities. The second issue raised by the participants was indigenization of activities carried out during the CPD. They commented that all CPD activities included theory, demonstration, practice with feedback, and coaching (3.44). As the duration of the CPD is one-week, the presenters' focus is on demonstration and they may not have enough time to explain aspects related to theoretical bases and or to perhaps practice with feedback, and coaching. To resolve this issue, it might be suggested that the duration of the CPD be extended.

The current study results also reveal that there is a sort of apprehension expressed by the participants regarding the effectiveness of the activities (3.30), and variety of activities designed for adult learners (3.28). Such concern might be attributed to the participants' varied educational backgrounds and experiences. Respondents also expressed their concern regarding follow-up activities. They mentioned that there is a norm of experimentation which permits them to try on new instructional practices (3.44), presence of ongoing discussion groups (3.36), and availability of continuous support and follow-up activities (3.12). The norm of follow-up seems missing or less-practiced.

\section{Conclusion}

The present research focused on the attitudes and perceptions of English language teachers toward professional development, activities, and obstacles which may hinder change or growth. The data collected through a questionnaire, responded to by the participants of a CPD, reflected that the teachers were aware of professional development as a need of the hour and indispensible to their academic and management skills. Majority of the teachers reflected that they set their goals to improve professionally and reflect upon their teaching, so they believed in teamwork and collaboration as well. Findings of the present study revealed that the CPD was essentially perceived as a learning activity, a challenge to think creatively and critically as a learner and as a teacher, and learning with and from their colleagues. However, respondents expressed their concerns regarding networking with colleagues, instructions from the experts, and discussion to help them in solving their classroom issues based on their impression of short duration of the CPD, large number of participants and seating arrangements.

After attending the CPD, in their feedback, the participants of the current study reiterated upgrading their professional and leadership skills realizing the importance of CPD in developing their teaching skills. They acknowledged that CPD provided them with a challenging change in their knowledge, skills, attitudes, and beliefs. Based on findings, there were CPD related demanding issues which needed urgent attention. These issues included concerns about institutional policies and support, indigenization of activities carried out during the CPD, and follow-up activities.

\subsection{Suggestions}

- CPD organizers and teacher educator should conduct a careful need analysis before designing and implementing professional development programs for language teachers. The need analysis should focus on teachers' beliefs about language teaching, what they know, and what they would like to know.

- Teacher educators must consider that theory and practice have a reciprocal relationship and both have a positive impact on teachers and their teaching. As such, a CPD may include theoretical input responding to the needs and which has to be identified in the need analysis prior to starting a CPD program with appropriate provision of explicit activities for teachers to discuss issues around theoretical underpinnings.

- CPD activities may combine both, theory and practice, to address planning and implementing teaching ideas and it may have follow-up sessions for reflection.

- There should be a close coordination between the teacher educators and the participants of a CPD to ensure a collaborative environment and active participation.

- There may be a systematic process of class observation which may help the teacher educator to monitor a teacher's progress while he or she is attending a CPD.

- The CPD objectives and activities may be aligned with the institutional policies. The institution needs to introduce a norm of experimentation permitting teachers to try on new instructional practices in their classroom.

- There should be discussion groups providing a chance to the teachers to share their ideas as a continuous support and follow-up activities.

\section{References}

Al-Manwari. Z. (2003). Peer Observation in cycle one schools in some Omani regions: Proposal. MA Dissertation. Sultan Qaboos University, Oman.

Al-Hashami, R. (2003). The training needs for Arabic teachers in secondary schools. MA Dissertation. Sultan Qaboos University, Oman.

Álvarez, G., \& Sánchez, C. (2005). Teachers in a public school engage in a study group to reach general agreements about a common approach to teaching English. PROFILE Issues in Teachers' Professional Development, 6(1), $119-132$.

Ariza, J., \& Ramos, D. (2010). The pursuit of professional development through a teacher study group (Unpublished master's thesis). Universidad de Caldas, Manizales.

Atikler, A. (1997). The role of action research in self-development of an ELT teacher: A descriptive case study. Unpublished master's thesis, Bilkent University, Ankara. 
Badia M. H. (2015). Teacher Evaluation as a Tool for Professional Development: A Case of Saudi Arabia. Advances in Language and Literary Studies.Vol.6 No. 5. 97-103

Bailey, K. (1992). The processes of innovation in language teacher development: What, why and how teachers change. In J. Flowerdew, M. Brock, \& S. Hsia (Eds.), Perspectives on second language teacher education (pp. 253-282). Hong Kong, China: City Polytechnic of Hong Kong.

Bailey, K., Curtis, A. \&Nunan, D. (2001). Pursuing professional development: the self as source. Boston, MA: Heinle\&Heinle.

Bailey, K. M., Curtis, A., and Nunan, D. (1998). Undeniable insights: The collaborative use of three professional development practices. Tesol Quarterly, 32(3), 159-169.

Darling-Hammond, L, \& McLaughlin, M.W. (1995). Policies that support professional development in an era of reform. Phil Delta Kappan, 76(8), 597-604.

David H., Olwen M., Janis J., Mary L., and Anne C. (2003). Teachers' Perceptions of Continuing Professional Development. Nottingham: Queen's Printer

Day, C. (1999). Developing teachers: The challenges of lifelong learning. London: Falmer Press.

Díaz-Maggioli, G. (2004). Teacher-centered professional development. Alexandria, VA: ASCD Publications.

Freeman, D. (1989). Teacher training, development, and decision making: A model of teaching and related strategies for language teacher education. TESOL Quarterly, 23(1), 27-45.

Fullan, M., \& Hargreaves, A. (2002). Teacher development and educational change. New York: Routledge.

Giraldo, F. (2014). The impact of a professional development program on English language teachers' classroom performance. PROFILE Issues in Teachers' Professional Development, 16(1), 63-76.

Golding, L., \& Gray, I. (2006). Continuing professional development for clinical psychologists: A practical handbook. Oxford: Blackwell Publishing

Hargreaves, A., and Fullan, M. G. (Eds.). (1992). Understanding teacher development. New York: Teachers College Press, Columbia University.

Hargreaves, A., \&Fullan, M. (1998). What's worth fighting for out there. New York: Teachers College.

Hayes, D. (2000). Cascade training and teachers' professional development. ELT Journal, 54(2), 135-145.

Jackson, P. W. (1992). Helping teachers develop. In A. Hargreaves and M. G. Fullan (Eds.), Understanding teacher development. New York: Teachers College Press, 62-74.

Jacobs, G., \& Farrell, T.S.C. (2001). Paradigm shift: Understanding and implementing change in second language education. TESL EJ, 5(1).

Jasper, M. (2006). Professional development, reflection, and decision-making. Oxford: Blackwell Publishing.

Karaaslan, A.D. (2003). Teachers' perceptions of self-initiated professional development: A case study on Bakent University English Language teachers. Unpublished master thesis submitted at Middle East Technical University. Retrieved on 30 August 2015 from https://etd.lib.metu.edu.tr/upload/1217736/index.pdf

Kerka, S. (2003). Does adult educator professional development make a difference: Myths and realities. Washington: ERIC Publications.

Lam, S., Yim, P., and Lam, T. W. (2002). Transforming school culture: Can true collaboration be initiated? Educational Research, 44(2), 181-195).

Lau, K. L. (2006). Implementing strategy instruction in Chinese language classes: A school-based Chinese reading strategy instruction program. Educational Research, 48(2), 195-209.

Little, J.W. (1993).Teachers' professional development in a climate of educational reform. Educational Evaluation and Policy Analysis, 15(2), 129-151.

Luke, A., \&McArdle, F. (2009).A model for research-based state professional development policy. Asia-Pacific Journal of Teacher Education, 37(3), 231-251.

Muijs, D., \& Harris, A. (2003). Teacher leadership - Improvement through empowerment? An overview of the literature. Educational management administration and leadership, 31, 437-448.

ORC International (2001) Time Well Spent: Work that teachers value. London: Association of Teachers and Lecturers.

Özdemir, P. (2001). The effectiveness of action research as a teacher development tool: A case study. Unpublished master's thesis, METU, Ankara.

Rényi, J. (1998). Building learning into teaching job. Educational Leadership, 55(5), 70-74.

Richards, J. C., \& Farrell, T. S. C. (2005). Professional development for language teachers: Strategies for teacher learning. Cambridge, UK: Cambridge University Press.

Shang, H.F. (2010). Reading strategy use, self-efficacy and EFL reading comprehension. Asian EFL Journal, 12(2), 1842. 
Sparks, D., \&Loucks-Horsley, S. (1990). Five models of staff development. Oxford, OH: National Staff Development Council.

Turhan, I.E. \&Arikan, A. (2009). English language teacher development with and without a teacher trainer: ELT instructors' perceptions. E-journal of New World Sciences Academy, 4(2). Retrieved May 8, 2015, from http://www.eric.ed.gov/PDFS/ED506221.pdf

Willis, J., \& Willis, D. (Eds.). (1996). Challenge and change in language teaching. Oxford: Heinemann.

Casteel, C.J. \&Ballantyne, K.G. (Eds.). (2010). Professional Development in Action: Improving Teaching for English Learners. Washington, DC: National Clearinghouse for English Language Acquisition. Retrieved 14 August 2015 from www.ncela.gwu.edu/files/uploads/3/PD_in_Action.pdf

David H. (Ed.). (2014). Innovations in the continuing professional development of English language teachers. London: British Council

Lee, I. (2011). Teachers as presenters at continuing professional development seminars in the English-as-a-foreignlanguage context: 'I find it more convincing'. Australian Journal of Teacher Education, 36(2). Pp. 30-42. Retrieved 8 September 2015 from http://dx.doi.org/10.14221/ajte.2011v36n2.3

Saud, M. A. (2015). Stages of Teacher's Professionalism: How Are English Language Teachers Engaged? Theory and Practice in Language Studies, Vol. 5, No. 4, pp. 671-678, April 2015. Retrieved 2 August 2015 from http://dx.doi.org/10.17507/tpls.0504.01

Sixel, Deborah Marie, "Teacher Perceptions of Professional Development Required by the Wisconsin Quality Educator Initiative, PI 34" (2013). Theses and Dissertations. Paper 160.

Yurtsever, G. (2012). English language i beliefs on professional development models and preferences to improve their teaching skills. Akdeniz Language Studies Conference 2012.Published by Elsevier Ltd. Pp.666-674. Retrieved 10 September 2015 from doi:10.1016/j.sbspro.2013.01.107 